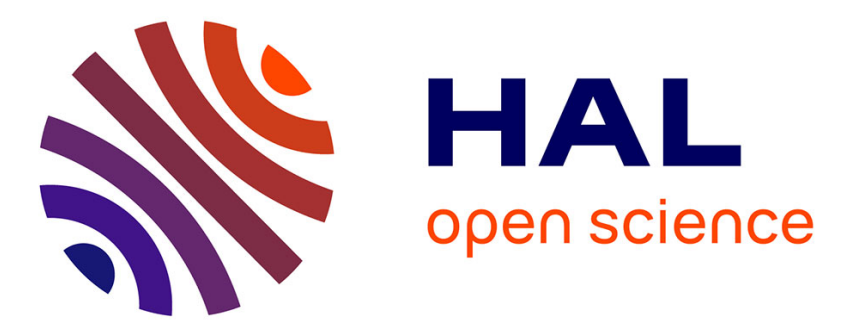

\title{
New route to 1-formylalkylphosphonates using diethyl trichloromethylphosphonate as a precursor
}

Yannick Zanella, Sylvie Berté-Verrando, Rachel Dizière, Philippe Savignac

\section{To cite this version:}

Yannick Zanella, Sylvie Berté-Verrando, Rachel Dizière, Philippe Savignac. New route to 1formylalkylphosphonates using diethyl trichloromethylphosphonate as a precursor. Journal of the Chemical Society, Perkin Transactions 1, 1995, 1 (22), pp.2835-2838. 10.1039/P19950002835 . hal03166527

\section{HAL Id: hal-03166527 https://hal.science/hal-03166527}

Submitted on 11 Mar 2021

HAL is a multi-disciplinary open access archive for the deposit and dissemination of scientific research documents, whether they are published or not. The documents may come from teaching and research institutions in France or abroad, or from public or private research centers.
L'archive ouverte pluridisciplinaire $\mathbf{H A L}$, est destinée au dépôt et à la diffusion de documents scientifiques de niveau recherche, publiés ou non, émanant des établissements d'enseignement et de recherche français ou étrangers, des laboratoires publics ou privés. 


\title{
New Route to 1-Formylalkylphosphonates Using Diethyl Trichloromethylphosphonate as Precursor
}

\author{
Yannick Zanella, Sylvie Berté-Verrando, Rachel Dizière and Philippe Savignac \\ Hétéroéléments et Coordination, URA CNRS 1499, DCPH, Ecole Polytechnique \\ 91128 PALAISEAU Cedex France
}

\begin{abstract}
Diethyl trichloromethylphosphonate $\mathbf{1}$ and chlorotrimethylsilane were converted in a threestep sequence by $\mathrm{BuLi}$ into $\alpha$-phosphorylated $\alpha$-silylated $\alpha$-substituted carbanions 4 . On reaction with ethyl formate in the presence of chlorotrimethylsilane they give transient silylated acetals $\mathbf{8}$ which are readily hydrolysed in acid medium into 1formylalkylphosphonates 7 which are isolated in good yields.
\end{abstract}

Diethyl trichloromethylphosphonate $\mathbf{1}$, which is readily available on laboratory scale $^{1}$ and also commercially, has already been pointed out as a useful starting material ${ }^{2}$. In a preceding paper we described a synthesis of medium size (4-6 membered) cycloalkylphosphonates ${ }^{3}$ based on the successive exchange of the three chlorine atoms of the phosphonate 1 . This process, which is summarized in Scheme 1, involves a three-step sequence. In the first step, addition of a mixture of diethyl trichloromethylphosphonate $\mathbf{1}$ and chlorotrimethylsilane (1.1 equiv.) to an excess of butyllithium (2.1 equiv.) in tetrahydrofurane (THF) at low temperature takes place through a double chlorine-lithium exchange to give the stable $\alpha$-phosphorylated $\alpha$-silylated $\alpha$-chlorinated carbanion $2\left(\delta^{31} \mathrm{P}(\mathrm{THF})+46.9\right)$. With these experimental conditions the condensation of two trimethylsilyl groups was never observed and alkylation of the carbanion 2 was achieved by reaction with alkyl halides ${ }^{4}$ ( $\mathrm{RX}$ with $\left.\mathrm{X}=\mathrm{Br}, \mathrm{I}\right)$. The so formed phosphonate $3\left(\delta^{31} \mathrm{P}(\mathrm{THF})+24.7\right)$ is then submitted to the third chlorine-lithium exchange at low temperature to give a new $\alpha$-phosphorylated $\alpha$-silylated $\alpha$-substituted stable 
carbanion 4 . One component only was observed by ${ }^{31} \mathrm{P}$ NMR analysis $\left(\delta^{31} \mathrm{P}(\mathrm{THF})+54\right)$ and the signal was assigned to carbanion 4. By the use of this sequence a large variety of intermediates 4 (a-h) have been cleanly and quantitatively prepared $\left(\mathrm{R}=\mathrm{C}_{3} \mathrm{H}_{7}, \mathrm{C}_{5} \mathrm{H}_{11}\right.$, $\left.\mathrm{C}_{7} \mathrm{H}_{15}, \mathrm{C}_{12} \mathrm{H}_{25}, \mathrm{CH}_{2}=\mathrm{CH}-\mathrm{CH}_{2}, \mathrm{CH}_{3}-\mathrm{CH}=\mathrm{CH}-\mathrm{CH}_{2}, \mathrm{Cl}-\mathrm{CH}_{2}-\left(\mathrm{CH}_{2}\right)_{2}, \mathrm{Cl}_{-} \mathrm{CH}_{2}-\left(\mathrm{CH}_{2}\right)_{3}\right)$ (Scheme 1).
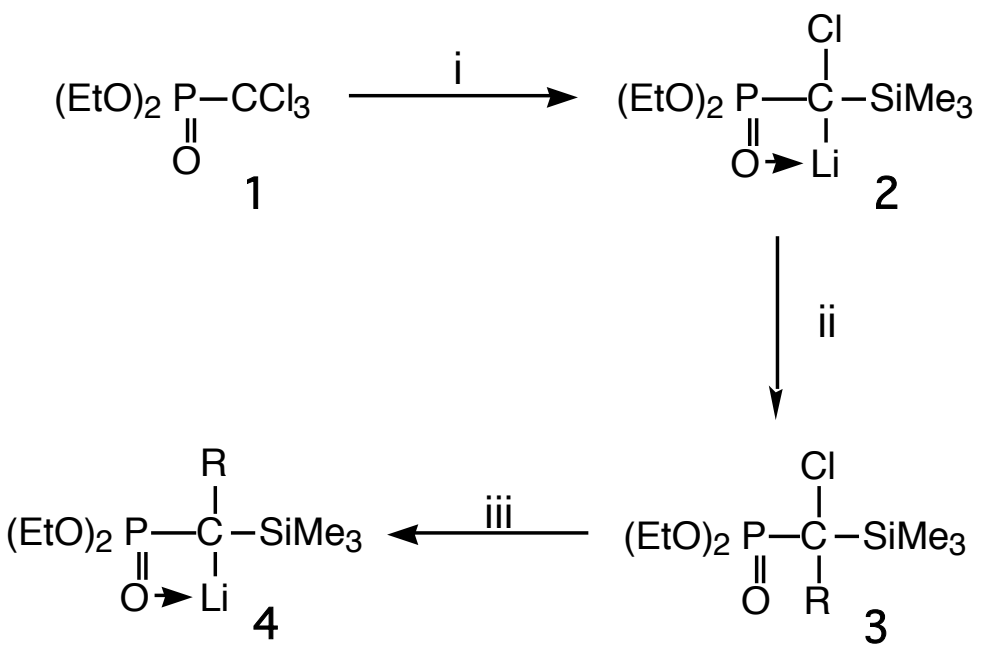

$$
\begin{gathered}
a \mathrm{R}=\mathrm{Pr}, \mathrm{X}=\mathrm{I}, \mathrm{bR}=\mathrm{CH}_{11}, \mathrm{X}=\mathrm{I} ; \mathrm{cR}=\mathrm{CH}_{15} \mathrm{X}=\mathrm{I} ; \\
\mathrm{dR}=\mathrm{G} \mathrm{H}_{25} \mathrm{X}=\mathrm{I} ; \mathrm{eR}=\mathrm{allyl}, \mathrm{X}=\mathrm{Br} \mathrm{f}=\mathrm{R}=\mathrm{crotyl}, \mathrm{X}=\mathrm{B} \\
\mathrm{gR}=\mathrm{Cl}-\mathrm{CH}_{2}\left(\mathrm{CH}_{2}\right)_{2}, \mathrm{X}=\mathrm{Br} ; \mathrm{hR}=\mathrm{Cl}-\mathrm{CH}_{2}-\left(\mathrm{CH}_{2}\right)_{3}, \mathrm{X}=\mathrm{Br} .
\end{gathered}
$$

Scheme 1 : Reagents and conditions : i, BuLi (2,1 mol equiv.), ClSiMe3 (1.1 mol equiv.), THF, $-80^{\circ} \mathrm{C}$; ii, $\mathrm{RX}, \mathrm{THF},-30^{\circ} \mathrm{C}$; iii, BuLi (1.1 mol equiv.), THF, $-80^{\circ} \mathrm{C}$.

\section{Results and Discussion}

We envisaged that the phosphorylated carbanions 4 could provide new intermediates in the synthesis of 1-formylalkylphosphonates 7 . Thus, on treatment of carbanions $\mathbf{4}$ with ethyl formate, Peterson type reaction to afford two (E) and (Z) phosphorylated enol ethers was expected to occur ${ }^{4}$ via the elimination of lithiated silanol, hydrolysis of the so formed enol ethers being achieved by treatment in acidic medium. Previous approaches to 1-formylalkyl phosphonates are based on the condensation of $\alpha$-lithioalkylphosphonates with dimethylformamide but limited by both the availability of the nucleophile and the reactivity of the electrophile ${ }^{5}$. In this paper we describe the results of experiments that were realized (i) to 
identify the factors that control the formation of $\mathbf{7}$ and (ii) to demonstrate the feasibility of this new approach. Two routes have been examined and each of these will be described in turn.

In the first route (Scheme 2), carbanion $4 \mathbf{a}\left(\mathrm{R}=\mathrm{C}_{3} \mathrm{H}_{7}\right)$ taken as template, was treated with ethyl formate (1.1 equiv.) in THF at low temperature to give in quantitative yield the lithiated hemiacetal 5a which spontaneously decomposes in an isomeric mixture of the two expected phosphorylated enol ethers 6a resulting from an exclusive Peterson type reaction and easily identified by ${ }^{31} \mathrm{P}$ NMR analysis $\left(\delta^{31} \mathrm{P}(\mathrm{THF})+20(\mathrm{E}),(75 \%)\right.$ and $\left.+25(\mathrm{Z}),(25 \%)\right)$. However, these were not isolated but, rather intercepted by directly pouring the cold crude product mixture into a cold biphasic mixture of hydrochloric acid (5M) and dichloromethane $\left(\mathrm{CH}_{2} \mathrm{Cl}_{2}\right)$. Upon stirring of two phosphorylated enol ethers $6 \mathbf{a}$ at $0^{\circ} \mathrm{C}$ over one hour the hydrolysis was complete and the corresponding 1-formyl 1-propylmethyl phosphonate 7a was isolated in reasonable yield $(55 \%)$ as a mixture of aldehyde $\left(\delta^{31} \mathrm{P}(\mathrm{THF})+23\right)$ and enol $\left(\delta^{31} \mathrm{P}(\mathrm{THF})+27,7\right)$ after purification by double extraction acid and base. When similar treatment was repeated but with the hydrolysis step being carried out with a more concentrated hydrochloric acid solution (12M), 7a was equally isolated in 55\% yield.

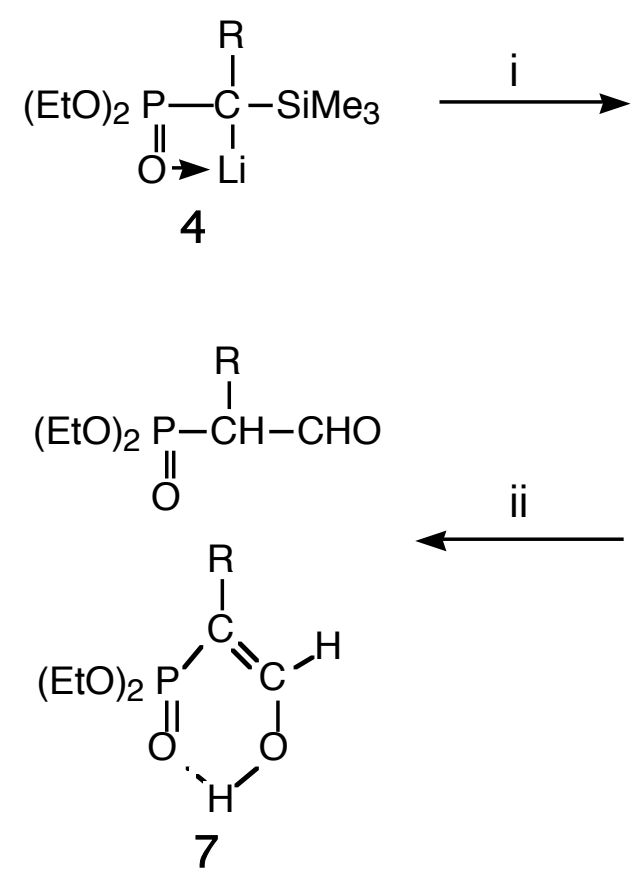<smiles>[R]C(C)([SiH3])C(O[AlH2])O[AlH]OCC</smiles>

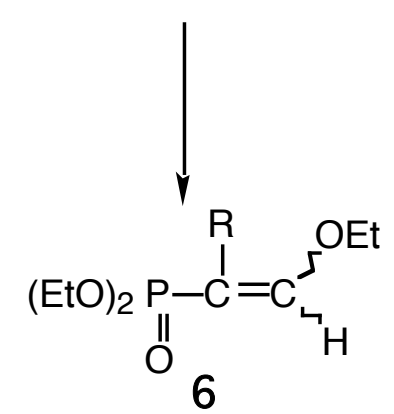

Scheme 2 : Reagents and conditions : i, HCOOEt (1.1 mol equiv.), THF, $-80^{\circ} \mathrm{C}$; ii, $\mathrm{HCl}$ $(5 \mathrm{M})-\mathrm{CH}_{2} \mathrm{Cl}_{2},-80^{\circ} \mathrm{C}$ to $0^{\circ} \mathrm{C}$. 
However, when the cold mixture of the two enol ethers $\mathbf{6 a}$ was heated to room temperature and treated at that temperature with hydrochloric acid $(5 \mathrm{M})$ the two enol ethers $6 \mathbf{6}$ did not behave in the same way as previously; hydrolysis was never complete and no evolution was observed after a while, thus it was not possible to isolate or purify the phosphorylated aldehyde 7a. Attention was next turned to the use of carbanions $4 \mathbf{b}$ and $\mathbf{4 e}$, as starting materials for the synthesis of 1-formylalkylphosphonates $\mathbf{7 b}$ and $\mathbf{7 e}$. Carbanions $\mathbf{4 b}$ and $\mathbf{4 e}$ reacted with ethylformate to give the phosphorylated enol ethers $\mathbf{6 b}$ and $\mathbf{6 e}$ and finally, on acid hydrolysis $6 \mathbf{b}$ and $\mathbf{6 e}$ behave in the same way as $\mathbf{6 a}$ to afford 1-formylalkylphosphonates $\mathbf{7 b}$ and $7 \mathbf{e}$ in low overall yields (30 and 50\%, respectively).

This first route being dependent on a balance of factors (steric, temperature, concentration, etc) which could not be easily overcome, a simple and efficient protocol for construction of 1-formylalkylphosphonates 7 has been developed using the formation of an intermediate mixed acetal 8. In the second route (Scheme 3) we assumed that the hydrolysis of a phosphorylated mixed acetal $\mathbf{8}$, more sensitive to acid hydrolysis than the phosphorylated enol ethers 6, could provide a new and better approach to 1-formylalkylphosphonates 7.<smiles></smiles><smiles>COCCO</smiles><smiles>[R]C([AsH3])(P=O)C(OC)OC</smiles>

8<smiles>[R]C(C#CC)=COC(C)C</smiles> 
Scheme 3 : Reagents and conditions : i, HCOOEt (1.1 mol equiv.), $\mathrm{ClSiMe}_{3}$ (1.5 mol equiv.), $\mathrm{THF},-90^{\circ} \mathrm{C}$; ii, $\mathrm{HCl}(2 \mathrm{M})-\mathrm{CH}_{2} \mathrm{Cl}_{2}, 20^{\circ} \mathrm{C}, 60 \mathrm{~min}$.

Thus, to investigate this approach, carbanion $4 \mathbf{a}\left(\mathrm{R}=\mathrm{C}_{3} \mathrm{H}_{7}\right)$ was allowed to react at low temperature $\left(-90^{\circ} \mathrm{C}\right)$ with ethyl formate $(1.1$ equiv.) in the presence of an excess of chlorotrimethylsilane (1.5 equiv.). On reaction the desired mixed acetal 8a was obtained as the major product $\left(\delta^{31} \mathrm{P}(\mathrm{THF})+32.5\right)(94 \%)$ with a small quantity of enol ethers $\mathbf{6 a}(6 \%)$. The reaction mixture was then allowed to return to room temperature and poured into a biphasic mixture of hydrochloric acid $(2 \mathrm{M})$ and $\mathrm{CH}_{2} \mathrm{Cl}_{2}$. After $60 \mathrm{~min}$ at room temperature (as judged by ${ }^{31} \mathrm{P}$ NMR analysis) 8a was completely hydrolysed to give a rather better overall yield of aldehyde $7 \mathbf{a}(73 \%)$ as a mixture of aldehyde $\left(\delta^{31} \mathrm{P}\left(\mathrm{THF}-\mathrm{CH}_{2} \mathrm{Cl}_{2}\right),+22\right)$ and enol $\left(\delta^{31} \mathrm{P}\left(\mathrm{THF}-\mathrm{CH}_{2} \mathrm{Cl}_{2}\right)+27\right)$ after purification by double extraction acid and base.

The preference for the silylated enol ethers 9 in Scheme 3 was related to the ease of nucleophilic displacement at the OSiMe3 ether group rather than the OEt ether group in the mixed acetal 8. The proposal, which is illustrated in Scheme 4, for the hydrolysis of phosphorylated mixed acetal 8 into the 1-formylalkylphosphonate 7, would involve initial nucleophilic attack of the silyl group to generate the intermediate $\alpha$-silylated $\alpha$-substituted formyl phosphonate $\mathbf{1 0}$. Given the $\alpha$-position of the silyl group to formyl group in $\mathbf{1 0},[1,3]$ rearrangement of $\mathbf{1 0}$ to deliver the transient silylated enol ether $\mathbf{9}$ becomes feasible, this one being more sensitive to acid hydrolysis than the corresponding OEt enol ether $\mathbf{6}$.

This type of rearrangement has not been rigorously proven but it was suggested by both the oxophilic character of silicium and the enol form and it was considered to be the most reasonable explanation for the easy and complete hydrolysis of the mixed acetal $\mathbf{8}$.

The preference for chlorotrimethylsilane as protecting group was confirmed after repeated reactions between carbanion $\mathbf{4 a}$ and other chlorosilanes. On reaction with chlorotriethylsilane three components were observed by ${ }^{31}$ P NMR analysis; one of which was the mixed acetal $\left(\delta^{31} \mathrm{P}(\mathrm{THF})+32.4\right)$ in reasonable yield $(41 \%)$ and two other signals were assigned to the enol ethers $\left(\delta^{31} \mathrm{P}(\mathrm{THF})+24.9\right.$ and +19.8$)$. With chlorotriisopropylsilane the corresponding mixed acetal was not detectable and the two enol ethers were the only products observed.The influence of the formylating agent has also been examined and, using dimethylformamide in 
association with chlorotrimethylsilane, formation of the corresponding mixed acetal was not detectable in the crude reaction mixture.

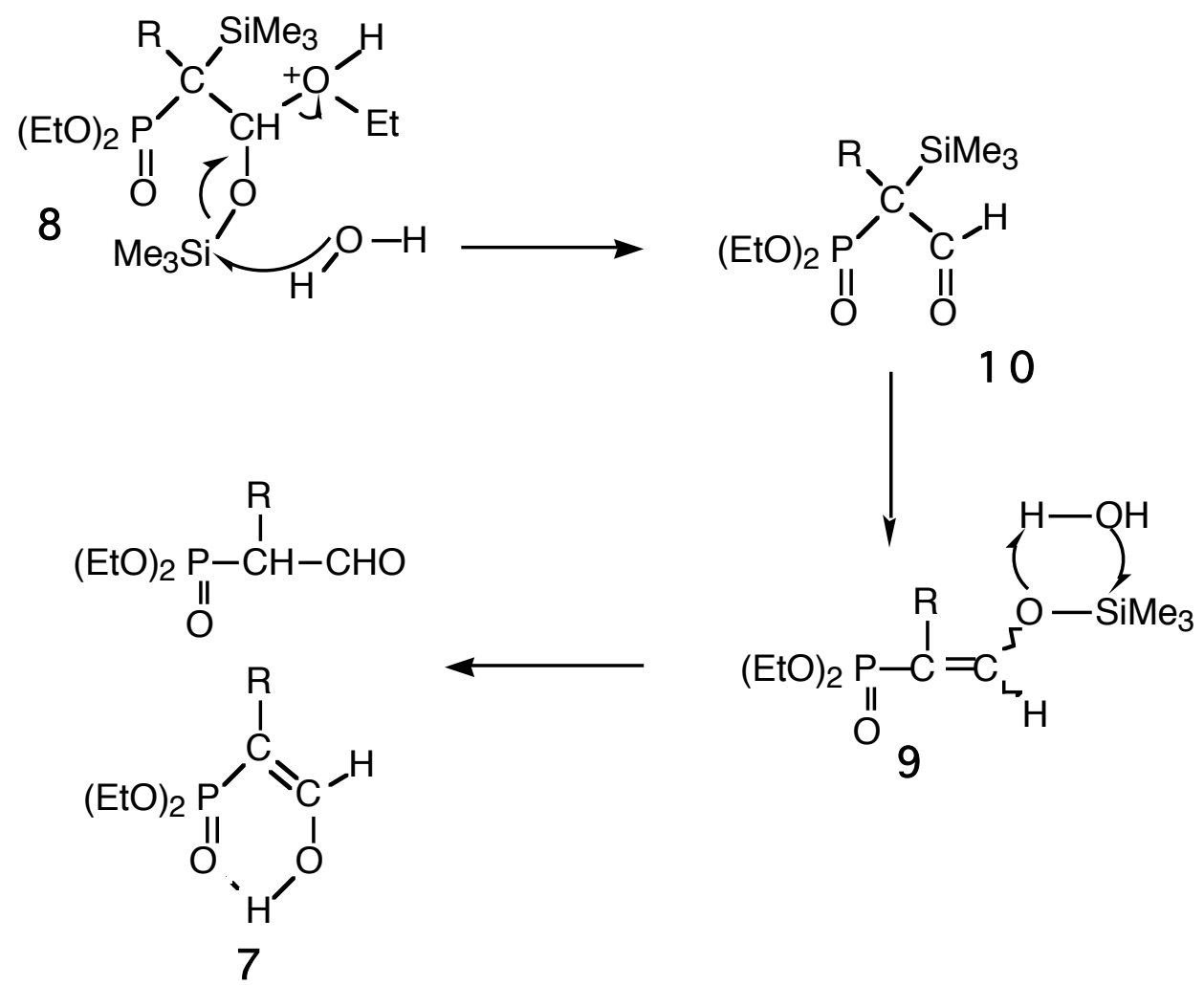

Scheme 4

Encouraged by these preliminary findings the synthesis of compounds 7 was explored in order to confirm the validity of the model reaction. Carbanions 4 (b-h) were prepared as described in Scheme 1 and in an analogous way put in reaction with ethyl formate and chlorotrimethylsilane in excess $\left(1.5\right.$ equiv.) at low temperature $\left(-90^{\circ} \mathrm{C}\right)$ in $\mathrm{THF}$. The influence of the alkyl moiety has been examined using saturated or unsaturated long chain. All were converted in quantitative yield into the desired mixed acetal $\mathbf{8}$ and on treatment in biphasic acid system underwent rearrangement and complete hydrolysis to give 1formylalkylphosphonates 7 (b-h) isolated in good yields (45-73\%) after purification by double extraction acid and base. Thus a series of 1-formylalkylphosphonates 7 (a-h) were synthesized and characterised. Structures of products were confirmed by $\mathrm{NMR}\left({ }^{1} \mathrm{H},{ }^{31} \mathrm{P}\right.$, and ${ }^{13} \mathrm{C}$ ) and mass spectrometry. 
In conclusion, this 'one-pot' procedure describes a new methodology for the synthesis of 1formylalkylphosphonates based on the condensation of $\alpha$-phosphorylated $\alpha$-silylated $\alpha-$ substituted carbanion with ethyl formate in the presence of chlorotrimethylsilane. It is interesting to note that the reported successive exchange of the three chlorine atoms of diethyl trichloromethylphosphonate $\mathbf{1}$ was very selective. In fact, no side-products were detected, showing that the possible polysilylation and the lithium-chlorine exchange pathways were uncompetitive reactions under these experimental conditions. Further work in this area is being focused on exploiting and extending the synthetic utility of diethyl trichloromethylphosphonate.

\section{Experimental}

${ }^{31} \mathrm{P}$ NMR, ${ }^{1} \mathrm{H}$ NMR and ${ }^{13} \mathrm{C}$ NMR spectra were recorded on a Bruker AC 200 instrument with $85 \% \mathrm{H}_{3} \mathrm{PO}_{4}$ as external standard (positive chemical shifts are downfield of this reference) for ${ }^{31} \mathrm{P} \mathrm{NMR}$ and $\mathrm{CDCl}_{3}$ as internal standard for ${ }^{1} \mathrm{H}$ NMR and ${ }^{13} \mathrm{C} \mathrm{NMR}$; coupling constants are given in Hz. High-resolution mass spectra (HRMS) were recorded on VG ZAB-HSQ or Bruker CMS 47\% ICR FT mass spectrometers. All reactions were carried out under an inert atmosphere and scrupulously anhydrous conditions. A Buchi GKR-50 apparatus with three flasks was used for distillation.The flask containing the crude product was in the upper part of the oven, and the collecting flask just outside.

\section{General Procedure for the Synthesis of 1-Formylalkylphosphonates $\mathbf{7} \mathbf{a - h}$}

Typical procedure for the synthesis of $\alpha$-Phosphorylated $\alpha$-silylated $\alpha$-substituted carbanions $4 \mathbf{a}-\mathbf{h}$ - .To a stirred mixture of a $1.6 \mathrm{M}$ hexane solution of BuLi $\left(53 \mathrm{~cm}^{3}, 84 \mathrm{mmol}\right)$ and dry THF $\left(100 \mathrm{~cm}^{3}\right)$ cooled to $-80^{\circ} \mathrm{C}$ were added dropwise trichloromethylphosphonate $(10.2 \mathrm{~g}, 40$ mmol) and $\mathrm{ClSiMe} 3(4.8 \mathrm{~g}, 44 \mathrm{mmol})$ in THF $\left(20 \mathrm{~cm}^{3}\right)$.Stirring was continued at $-80^{\circ} \mathrm{C}$ for about 15 min until formation of carbanion 2 was complete, as indicate by ${ }^{31} \mathrm{P}$ NMR spectroscopy. The alkyl halide (RX) $(44 \mathrm{mmol})$ in THF $\left(10 \mathrm{~cm}^{3}\right)$ was added dropwise at - 
$30^{\circ} \mathrm{C}$ then the stirred mixture was allowed to warm to room temperature until formation of phosphonate 3 was complete as prooved by ${ }^{31}$ P NMR spectroscopy. The mixture was cooled to $-80^{\circ} \mathrm{C}$ and a solution of Buli in hexane $\left(28 \mathrm{~cm}^{3}, 44 \mathrm{mmol}\right)$ was added at this temperature. After few minutes carbanion $\mathbf{4}$ was obtained quantitatively.

\section{via Enol ether route $\mathbf{7 a}$}

Ethyl formate $(3.3 \mathrm{~g}, 44 \mathrm{mmol})$ in THF $\left(20 \mathrm{~cm}^{3}\right)$ was added dropwise at $-80^{\circ} \mathrm{C}$. The mixture was stirred for $15 \mathrm{~min}$ at this temperature then poured into an ice-cold mixture of hydrochloric acid $\left(40 \mathrm{~cm}^{3}\right.$ of $5 \mathrm{M}$ solution) and dichloromethane $\left(40 \mathrm{~cm}^{3}\right)$ and stirred at this temperature for $60 \mathrm{~min}$. The aqueous layer was extracted with dichloromethane $\left(3 \times 30 \mathrm{~cm}^{3}\right)$. then washed with a solution of sodium hydroxide $\left(3 \times 35 \mathrm{~cm}^{3}\right.$ of $2 \mathrm{M}$ solution $)$. The aqueous layers were separated and treated with hydrochloric acid $(12 \mathrm{M})$ until acidic $\mathrm{pH}$ then extracted with dichloromethane $\left(3 \times 30 \mathrm{~cm}^{3}\right)$. The organic layers were separated, washed with water $\left(15 \mathrm{~cm}^{3}\right)$, dried $\left(\mathrm{MgSO}_{4}\right)$ and evaporated under reduced pressure to afford crude product which was purified by distillation under reduced pressure using bulb-to-bulb apparatus.

\section{via Mixed acetal route $\mathbf{7 a - h}$}

A mixture of ethyl formate $(3.3 \mathrm{~g}, 44 \mathrm{mmol})$ and chlorotrimethylsilane $(6.5 \mathrm{~g}, 60 \mathrm{mmol})$ in THF $\left(20 \mathrm{~cm}^{3}\right)$ were added dropwise at $-90^{\circ} \mathrm{C}$. The mixture was stirred for $15 \mathrm{~min}$ at this temperature then allowed to warm to room temperature and poured into an ice -cold mixture of hydrochloric acid $\left(55 \mathrm{~cm}^{3}\right.$ of $2 \mathrm{M}$ solution) and dichloromethane $\left(40 \mathrm{~cm}^{3}\right)$ and stirred at this temperature for $60 \mathrm{~min}$. The aqueous layer was extracted with dichloromethane $(3 \times 30$ $\left.\mathrm{cm}^{3}\right)$. then washed with a solution of sodium hydroxide $\left(3 \times 35 \mathrm{~cm}^{3}\right.$ of $2 \mathrm{M}$ solution $)$. The aqueous layers were separated and treated with hydrochloric acid (12 M) until acidic pH then extracted with dichloromethane $\left(3 \times 30 \mathrm{~cm}^{3}\right)$. The organic layers were separated, washed with water $\left(15 \mathrm{~cm}^{3}\right)$, dried $\left(\mathrm{MgSO}_{4}\right)$ and evaporated under reduced pressure to afford crude product which was purified by distillation under reduced pressure using bulb-to-bulb apparatu. The large temperature range is due to the distillation of a mixture of the keto-enol tautomers. 
(73\%), b.p. $(20 \mathrm{mmHg}) 175-190^{\circ} \mathrm{C} ; \delta \mathrm{P}\left(\mathrm{CDCl}_{3}\right)+23.17$ and $+27.76 ; \delta \mathrm{H}\left(\mathrm{CDCl}_{3}\right) 0.94\left(\mathrm{t},{ }^{3} \mathrm{~J} \mathrm{H}-\right.$ $\left.\left.\mathrm{H} 7, \mathrm{CH}_{3}-\left(\mathrm{CH}_{2}\right) 2\right)\right), 1.35$ (t, $\left.{ }^{3} \mathrm{~J}_{\mathrm{H}-\mathrm{H}} 7, \mathrm{CH}_{3}-\mathrm{CH}_{2}-\mathrm{O}\right), 1.9\left(\mathrm{~m}, \mathrm{CH}_{3}-\left(\mathrm{CH}_{2}\right) 2\right), 3\left(\mathrm{dm},{ }^{2} \mathrm{~J}_{\mathrm{H}-\mathrm{P}}\right.$ 26, P-CH-CHO), 4.16 (m, CH3-CH2-O), $9.65\left(\mathrm{~d},{ }^{3} \mathrm{~J} H-\mathrm{H}_{3} 3, \mathrm{CHO}\right)$; $\delta \mathrm{C}\left(\mathrm{CDCl}_{3}\right) 13.9$ (s, $\mathrm{CH}_{3}-$ $\left(\mathrm{CH}_{2}\right)_{2}$, aldehyde), 14.2 (s, $\mathrm{CH}_{3}-\left(\mathrm{CH}_{2}\right)_{2}$, enol), 16.4 (d, ${ }^{3}{ }^{\mathrm{J}} \mathrm{C}-\mathrm{P} 6.3, \mathrm{CH}_{3}-\mathrm{CH}_{2}-\mathrm{O}$, enol), 16.5 (d, ${ }^{3} \mathrm{~J}_{\mathrm{C}-\mathrm{P}}$ 6, $\mathrm{CH}_{3}-\mathrm{CH}_{2}-\mathrm{O}$, aldehyde), 21.7 (d, JC-P 13.7, $\mathrm{CH} 2$, aldehyde), 22.1 (s, $\mathrm{CH}_{2}$, enol), 25.8 (d, JC-P 4.6, $\mathrm{CH}_{2}$, aldehyde), 26.1 (d, JC-P 6.5, $\mathrm{CH}_{2}$, enol), 53.0 (d, JC-P 126.6, CH$\mathrm{CHO}), 61.5$ (d, ${ }^{2} \mathrm{~J}_{\mathrm{C}-\mathrm{P}} 5.6, \mathrm{CH}_{2}-\mathrm{O}$, enol), 63.1 (d, ${ }^{2} \mathrm{~J}_{\mathrm{C}-\mathrm{P}} 7.5, \mathrm{CH}_{2}-\mathrm{O}$, aldehyde), 99.5 (d, JC-P 196.3, $C=\mathrm{CHOH}), 157.2$ (d, $\left.{ }^{2} \mathrm{~J}_{\mathrm{C}-\mathrm{P}} 29.0,=\mathrm{CHOH}\right), 196.3$ (d, $\left.{ }^{2} \mathrm{~J}_{\mathrm{C}-\mathrm{P}} 4.5,-\mathrm{CHO}\right)$. (HRMS) (Found: $\mathrm{M}^{+}, 222,1020$. Calc for $\mathrm{C}_{9} \mathrm{H}_{19 O} \mathrm{OP}: \mathrm{M}, 222.1020$.

O,O-Diethyl 1-pentyl 2-oxoethylphosphonate $\mathbf{7 b}$

(73\%), b.p. $(20 \mathrm{mmHg}) \quad 185-200^{\circ} \mathrm{C} ; \delta \mathrm{P}\left(\mathrm{CDCl}_{3}\right)+22.47$ and $+27.40 . \delta_{\mathrm{H}}\left(\mathrm{CDCl}_{3}\right) 0.83(\mathrm{t}$, $\left.{ }^{3} \mathrm{~J}_{\mathrm{H}-\mathrm{H}} 6.5,\left(\mathrm{CH}_{2}\right) 4-\mathrm{CH}_{3}\right), 1.25\left(\mathrm{dt},{ }^{3} \mathrm{~J}_{\mathrm{H}-\mathrm{H}} 7, \mathrm{CH}_{3}-\mathrm{CH}_{2}-\mathrm{O}\right), 1.9\left(\mathrm{~m}, \mathrm{CH}_{3}-\left(\mathrm{CH}_{2}\right) 3-\mathrm{CH}_{2}\right), 2.9$ $\left(\mathrm{dm},{ }^{2} \mathrm{~J}_{\mathrm{H}-\mathrm{P}} 25, \mathrm{P}-\mathrm{CH}-\mathrm{CHO}\right), 4.10\left(\mathrm{~m}, \mathrm{CH}_{3}-\mathrm{CH}_{2}-\mathrm{O}\right), 9.65\left(\mathrm{~d},{ }^{3} \mathrm{~J}_{\mathrm{H}-\mathrm{H}} 3, \mathrm{CHO}\right) ; \delta_{\mathrm{C}}\left(\mathrm{CDCl}_{3}\right)$ 14.4 (s, $\left.\mathrm{CH}_{3}-\left(\mathrm{CH}_{2}\right) 4\right), 16.6$ (s, $\left.{ }^{3} \mathrm{~J}_{\mathrm{C}-\mathrm{P}} 6.8, \mathrm{CH}_{3}-\mathrm{CH}_{2}-\mathrm{O}\right), 22.7$ (s, $\mathrm{CH}_{2}$, aldehyde), 22.9 (s, $\mathrm{CH}_{2}$, enol), 24.2 (d, ${ }^{3}{ }_{\mathrm{J}} \mathrm{C}-\mathrm{P} 6.3, \mathrm{CH}_{2}$, enol), 28.4 (d, ${ }^{2} \mathrm{~J}_{\mathrm{C}-\mathrm{P}} 13.3, \mathrm{CH}_{2}$, aldehyde), 28.7 (s, $\mathrm{CH}_{2}$, enol), 31.9 (s, $\mathrm{CH}_{2}$, enol), 32.2 (s, $\mathrm{CH}_{2}$, aldehyde), 53.5 (d, JC-P 126.6, $\mathrm{CH}$-CHO), 61.7 (d, ${ }^{2} \mathrm{~J}_{\mathrm{C}-\mathrm{P}} 4.6, \mathrm{CH}_{2}-\mathrm{O}$, enol), 63.3 (d, ${ }^{2} \mathrm{~J}_{\mathrm{C}-\mathrm{P}} 6.9, \mathrm{CH}_{2}-\mathrm{O}$, aldehyde), 99.8 (d, JC-P 195.6, $C=\mathrm{CHOH}), 157.4\left(\mathrm{~d},{ }^{2} \mathrm{~J}-\mathrm{P} 29.2,=\mathrm{CHOH}\right), 196.8(\mathrm{~s}, \quad-\mathrm{CHO}) .(\mathrm{HRMS})\left(\right.$ Found: $\mathrm{M}^{+}$, 250,1333.Calc. for $\mathrm{C}_{11} \mathrm{H}_{23} \mathrm{O} 4 \mathrm{P}: \mathrm{M}, 250,1333$.

O,O-Diethyl 1-heptyl 2-oxoethylphosphonate 7c

(72\%), b.p. $(20 \mathrm{mmHg}) 205-215^{\circ} \mathrm{C} ; \delta \mathrm{P}\left(\mathrm{CDCl}_{3}\right)+22.47$ and $+27.40 ; \delta \mathrm{H}\left(\mathrm{CDCl}_{3}\right) 0.81(\mathrm{t}$, $\left.{ }^{3} \mathrm{~J}_{\mathrm{H}-\mathrm{H}} 6.4,\left(\mathrm{CH}_{2}\right) 4-\mathrm{CH}_{3}\right), 1.28\left(\mathrm{dt},{ }^{3} \mathrm{~J}_{\mathrm{H}-\mathrm{H}} 7, \mathrm{CH}_{3}-\mathrm{CH}_{2}-\mathrm{O}, 1.9\left(\mathrm{~m}, \mathrm{CH}_{3}-\left(\mathrm{CH}_{2}\right)_{5}-\mathrm{CH}_{2}\right), 2.9\right.$ $\left(\mathrm{dm},{ }^{2} \mathrm{~J}_{\mathrm{H}-\mathrm{P}} 25, \mathrm{P}-\mathrm{CH}-\mathrm{CHO}, 4.10\left(\mathrm{~m}, \mathrm{CH}_{3}-\mathrm{CH}_{2}-\mathrm{O}\right), 9.58\left(\mathrm{~d},{ }^{3} \mathrm{~J}_{\mathrm{H}-\mathrm{H}} 3, \mathrm{CHO}\right) ; \delta_{\mathrm{C}}\left(\mathrm{CDCl}_{3}\right)\right.$ 14.2 (s, $\left.\mathrm{CH}_{3}-\left(\mathrm{CH}_{2}\right) 6\right), 16.3$ (d, ${ }^{3} \mathrm{~J} \mathrm{C}-\mathrm{P}$ 6.6, $\mathrm{CH}_{3}-\mathrm{CH}_{2}-\mathrm{O}$, enol), 16.4 (d, ${ }^{3} \mathrm{~J}_{\mathrm{C}-\mathrm{P}} 5.7, \mathrm{CH}_{3}-\mathrm{CH}_{2}-$ O, aldehyde), 22.7 (s, $\mathrm{CH} 2$, aldehyde), 22.8 (s, $\mathrm{CH}_{2}$, enol), 23.6 (d, JC-P 4.4, $\mathrm{CH}_{2}$, aldehyde), 23.9 (d, JC-P 6.2, $\mathrm{CH}_{2}$, enol), 28.4 (d, JC-P 13.4, $\mathrm{CH}_{2}$ aldehyde), 28.8 (s, $\mathrm{CH}_{2}$ enol), 29.0 (s, $\mathrm{CH}_{2}$ aldehyde), 29.3 (s, $\mathrm{CH}_{2} \mathrm{enol}$ ), 29.4 (s, $\mathrm{CH}_{2}$ aldehyde), 29.7 (s, $\mathrm{CH}_{2}$ enol), 31.8 (s, $\mathrm{CH}_{2}$ aldehyde), 32.0 (s, $\mathrm{CH}_{2}$ enol), 53.1 (d, JC-P 126.5, $\mathrm{CH}$-CHO), 61.3 (d, ${ }^{2} \mathrm{~J}_{\mathrm{C}-\mathrm{P}} 4.7, \mathrm{CH}_{2}-\mathrm{O}$, enol), 62.9 (d, ${ }^{2} \mathrm{~J}_{\mathrm{C}-\mathrm{P}}$ 6.7, $\mathrm{CH}_{2}-\mathrm{O}$, aldehyde), 99.5 (d, JC-P 196.1, $\left.C=\mathrm{CHOH}\right), 157.0\left(\mathrm{~d},{ }^{2} \mathrm{~J}_{\mathrm{C}-\mathrm{P}}\right.$ 
29.2, =CHOH), 196.1 (s,-CHO). (HRMS) (Found: $\mathrm{M}^{+}, 278,1646$. Calc. for $\mathrm{C}_{13} \mathrm{H}_{27 \mathrm{O}} \mathrm{P} \mathrm{M}$, 278.1646 .

O,O Diethyl 1-dodecyl 2-oxoethylphosphonate 7d

(69\%), b.p. (20 mmHg) $210-225^{\circ} \mathrm{C} ; \delta_{\mathrm{H}}\left(\mathrm{CDCl}_{3}\right)+22.76$ and $+28.45 ; \delta_{\mathrm{H}}\left(\mathrm{CDCl}_{3}\right) 0.88(\mathrm{t}$, $\left.{ }^{3} \mathrm{~J}_{\mathrm{H}-\mathrm{H}} 6.4,\left(\mathrm{CH}_{2}\right){ }_{11}-\mathrm{CH}_{3}\right), 1.26\left(\mathrm{~m}, \mathrm{CH}_{3}-\mathrm{CH}_{2}-\mathrm{O}\right.$ and $\left.\mathrm{CH}_{3}-\left(\mathrm{CH}_{2}\right) 10-\mathrm{CH}_{2}\right), 1.9\left(\mathrm{~m}, \mathrm{CH}_{2}-\right.$ ( $\left.\left.\mathrm{CH}_{2}\right) 5-\mathrm{CH}_{3}\right), 2.1$ (m, P-CH-CH2), 4.0 (m, $\left.\left.\mathrm{CH}_{3}-\mathrm{CH}_{2}-\mathrm{O}\right)\right), 7.37$ (d, ${ }^{3} \mathrm{~J}_{\mathrm{H}-\mathrm{H}}$ 10.7, P$\mathrm{C}=\mathrm{CHOH}), 9.60\left(\mathrm{~d},{ }^{3} \mathrm{~J}_{\mathrm{H}-\mathrm{H}} 3, \mathrm{CHO}\right) \delta_{\mathrm{C}}\left(\mathrm{CDCl}_{3}\right) 14.1\left(\mathrm{~s}, \mathrm{CH}_{3}-\left(\mathrm{CH}_{2}\right) 11\right), 16.2\left(\mathrm{~d},{ }^{3} \mathrm{~J}_{\mathrm{C}-\mathrm{P}} 5.9\right.$, $\mathrm{CH}_{3}-\mathrm{CH}_{2}-\mathrm{O}$, aldehyde), 16.4 (d, ${ }^{3}{ }_{\mathrm{J}} \mathrm{C}-\mathrm{P} 5.3, \mathrm{CH}_{3}-\mathrm{CH}_{2}-\mathrm{O}$, enol), 22.7 (s, $\mathrm{CH}_{2}$ ), 23.5 (d, JC-P 4.5, $\mathrm{CH}_{2}$, enol), 23.8 (d, JC-P 6.2, $\mathrm{CH}_{2}$, aldehyde), 28.3 (d, JC-P 13.6, $\mathrm{CH}_{2}$, enol), 28.9 (d, JC-P 22.1, $\mathrm{CH}_{2}$, aldehyde), $29.3\left(\mathrm{~s}, \mathrm{CH}_{2}\right), 29.4$ (s, $\left.\mathrm{CH}_{2}\right), 29.6$ (s, $\left.\mathrm{CH}_{2}\right), 29.7\left(\mathrm{~s}, \mathrm{CH}_{2}\right), 32.0$ (s, $\mathrm{CH}_{2}$ ), 53.9 (d, JC-P 126.3, $\left.\mathrm{CH}-\mathrm{CHO}\right), 60.9$ (d, ${ }^{2} \mathrm{~J}_{\mathrm{C}-\mathrm{P}} 5.0, \mathrm{CH}_{2}-\mathrm{O}$, aldehyde), 62.5 (d, ${ }^{2} \mathrm{~J}_{\mathrm{C}-\mathrm{P}} 6.8, \mathrm{CH}_{2}-\mathrm{O}$, enol), $100.0\left(\mathrm{~d}, \mathrm{~J}_{\mathrm{C}-\mathrm{P}} 195.2, \mathrm{C}=\mathrm{CHOH}\right), 156.5\left(\mathrm{~d},{ }^{2} \mathrm{~J}_{\mathrm{C}-\mathrm{P}} 29.1=C H O H\right)$, 196.1(d, ${ }^{2} \mathrm{~J}_{\mathrm{C}-\mathrm{P}} 4.5,-\mathrm{CHO}$ ). (HRMS) (Found: $\mathrm{M}^{+}, 348.2429$. Calc. for $\mathrm{C}_{18} \mathrm{H}_{37 \mathrm{O}} \mathrm{P}: \mathrm{M}$, 348.2429 .

O,O-Diethyl 1-(2-propenyl) 2-oxoethylphosphonate 7e

$(58 \%)$, b.p. $(20 \mathrm{mmHg}) 160-180^{\circ} \mathrm{C} ; \delta \mathrm{P}\left(\mathrm{CDCl}_{3}\right)+22.04$ and $+2713 ; \delta_{\mathrm{H}}\left(\mathrm{CDCl}_{3}\right) 1.29(\mathrm{t}$, $\left.{ }^{3} \mathrm{~J}_{\mathrm{H}-\mathrm{H}} 7, \mathrm{CH}_{3}-\mathrm{CH}_{2}-\mathrm{O}\right), 2.71\left(\mathrm{~m}, \mathrm{CH}_{2}-\mathrm{CH}=\mathrm{CH}_{2}\right), 3.01\left(\mathrm{dm},{ }^{2} \mathrm{~J}_{\mathrm{H}-\mathrm{P}} 26, \mathrm{P}-\mathrm{CH}-\mathrm{CHO}\right), 4.11(\mathrm{~m}$, $\left.\left.\mathrm{CH}_{3}-\mathrm{CH}_{2}-\mathrm{O}\right)\right), 5.0\left(\mathrm{~m}, \mathrm{CH}_{2}-\mathrm{CH}=\mathrm{CH}_{2}\right), 5.73\left(\mathrm{~m}, \mathrm{CH}_{2}-\mathrm{CH}=\mathrm{CH}_{2}\right), 9.60\left(\mathrm{~d},{ }^{3} \mathrm{~J}_{\mathrm{H}-\mathrm{H}} 2.5 \mathrm{CHO}\right)$; $\delta_{\mathrm{C}}\left(\mathrm{CDCl}_{3}\right) 16.4\left(\mathrm{~d},{ }^{3} \mathrm{~J}_{\mathrm{C}-\mathrm{P}} 6.7, \mathrm{CH}_{3}-\mathrm{CH}_{2}-\mathrm{O}\right.$ enol), $16.6\left(\mathrm{~d},{ }^{2} \mathrm{~J}_{\mathrm{C}-\mathrm{P}} 8.2, \mathrm{CH}_{3}-\mathrm{CH}_{2}-\mathrm{O}\right.$ aldehyde), 28.0 (d, ${ }^{2} \mathrm{~J}_{\mathrm{C}-\mathrm{P}} 3.8, \mathrm{CH}_{2}-\mathrm{CH}=$ aldehyde), $28.3\left(\mathrm{~d},{ }^{2} \mathrm{~J}_{\mathrm{C}-\mathrm{P}} 6.9, \mathrm{CH}_{2}-\mathrm{CH}=\mathrm{enol}\right), 52.6$ (d, JC-P 125.5, CH-CHO), 61.7 (d, ${ }^{2} \mathrm{~J}_{\mathrm{C}-\mathrm{P}} 4.5, \mathrm{CH}_{2}-\mathrm{O}$ enol), 63.4 (d, ${ }^{2} \mathrm{~J}_{\mathrm{C}-\mathrm{P}} 6.9, \mathrm{CH}_{2}-\mathrm{O}$ aldehyde), 97.4 (d, JC-P 199.2, $\mathrm{C}=\mathrm{CHOH}), 115.0$ (s, $\mathrm{CH}=\mathrm{CH}_{2}$ enol), 117.7 (s, $\mathrm{CH}=\mathrm{CH}_{2}$ aldehyde), 134.5 (d, ${ }^{3} \mathrm{~J}_{\mathrm{C}-\mathrm{P}} 14.1, \mathrm{CH}=\mathrm{CH}_{2}$ aldehyde), 136.0 (s, $\mathrm{CH}=\mathrm{CH} 2 \mathrm{enol}$ ), 157.8 (d, $\left.{ }^{2} \mathrm{~J}_{\mathrm{C}-\mathrm{P}} 28.9,=C H O H\right), 195.9(\mathrm{~m}, \mathrm{CHO})$. (HRMS) (Found: $\mathrm{M}^{+}, 220 ., 0864$. Calc. for $\mathrm{C}_{9} \mathrm{H}_{17} \mathrm{O} 4 \mathrm{P} ; \mathrm{M}, 220.0864$.

O,O Diethyl 1-(2-butenyl) 2-oxoethylphosphonate $7 \mathbf{f}$

(55\%), b.p. $(20 \mathrm{mmHg}) 205-210^{\circ} \mathrm{C} ; \delta \mathrm{P}\left(\mathrm{CDCl}_{3}\right)+22.12$ and $+27.32 ; \delta \mathrm{H}\left(\mathrm{CDCl}_{3}\right) 1.32(\mathrm{t}$, $\left.\left.{ }^{3} \mathrm{~J}_{\mathrm{H}-\mathrm{H}} 7, \mathrm{CH}_{3}-\mathrm{CH}_{2}-\mathrm{O}\right)\right), 1.61\left(\mathrm{~d},{ }^{3} \mathrm{~J}_{\mathrm{H}-\mathrm{H}} 6, \mathrm{CH}_{3}-\mathrm{CH}=\mathrm{CH}-\mathrm{CH}_{2}\right), 2.59\left(\mathrm{~m}, \mathrm{CH}_{3}-\mathrm{CH}=\mathrm{CH}-\right.$ $\left.\left.\mathrm{CH}_{2}\right), 3.0\left(\mathrm{dm},{ }^{2} \mathrm{JP}-\mathrm{H} 26, \mathrm{P}-\mathrm{CH}-\mathrm{CHO}\right), 4.19\left(\mathrm{~m}, \mathrm{CH}_{3}-\mathrm{CH}_{2}-\mathrm{O}\right)\right), 5.38\left(\mathrm{~m}, \mathrm{CH}_{3}-\mathrm{CH}=\mathrm{CH}-\right.$ 
$\left.\mathrm{CH}_{2}\right), 5.49\left(\mathrm{~m}, \mathrm{CH}_{3}-\mathrm{CH}=\mathrm{CH}-\mathrm{CH}_{2}\right), 9.60\left(\mathrm{~d},{ }^{3} \mathrm{~J}_{\mathrm{H}-\mathrm{H}} 3, \mathrm{CHO}\right) ; \delta_{\mathrm{C}}\left(\mathrm{CDCl}_{3}\right) 16.5\left(\mathrm{~d},{ }^{3} \mathrm{~J}_{\mathrm{C}-\mathrm{P}}\right.$ 7.2, $\mathrm{CH}_{3}-\mathrm{CH}_{2}-\mathrm{O}$ enol), 16.7 (d, ${ }^{3} \mathrm{~J}-\mathrm{P} 9.3, \mathrm{CH}_{3}-\mathrm{CH}_{2}-\mathrm{O}$ aldehyde), 18.1 (s, $\mathrm{CH}_{3}-\mathrm{CH}=\mathrm{CH}$ ), $27.2\left(\mathrm{~d},{ }^{2} \mathrm{~J}_{\mathrm{C}-\mathrm{P}} 6.1, \mathrm{CH}_{2}-\mathrm{CH}=\mathrm{CH}\right), 53.8$ (d, JC-P 126.6, $\mathrm{CH}$-CHO), $61.8\left(\mathrm{~d},{ }^{2} \mathrm{~J}_{\mathrm{C}-\mathrm{P}} 4.1, \mathrm{CH}_{2}-\right.$ $\mathrm{O}$ enol), 63.3 (d, ${ }^{2} \mathrm{~J}_{\mathrm{C}-\mathrm{P}}$ 6.7, $\mathrm{CH}_{2}-\mathrm{O}$ aldehyde), 98.2 (d, $\mathrm{J}_{\mathrm{C}-\mathrm{P}}$ 197.4, $\left.\mathrm{C}=\mathrm{CHOH}\right), 125.6$ (s, $\left.\mathrm{CH}=\mathrm{CH}_{2} \mathrm{enol}\right), 127.1\left(\mathrm{~d},{ }^{3} \mathrm{~J}_{\mathrm{C}-\mathrm{P}} 13.9, \mathrm{CH}_{2}-\mathrm{CH}=\right.$ aldehyde $), 128.7(\mathrm{~s}, \mathrm{CH} 2-\mathrm{CH}=\mathrm{enol}), 134.5$ (d, ${ }^{3} \mathrm{~J}_{\mathrm{C}-\mathrm{P}} 14.1, \mathrm{CH}=\mathrm{CH}_{2}$ aldehyde), 136.0 (s, $\mathrm{CH}=\mathrm{CH}_{2}$ enol), 157.6 (d, ${ }^{2} \mathrm{~J}_{\mathrm{C}-\mathrm{P}} 30.2$, $=\mathrm{CHOH}$ ), $196.4(\mathrm{~m}, \mathrm{CHO})$. (HRMS) (Found $\mathrm{M}^{+}, 234,1029$. Calc. for. $\mathrm{C}_{10} \mathrm{H}_{19} \mathrm{O}_{4} \mathrm{P}$; M,234., 1029 .

O,O Diethyl 1-(3-Chloropropyl) 2-oxoethylphosphonate $\mathbf{7 g}$ (45\%), b.p. $(20 \mathrm{mmHg}) 190-205^{\circ} \mathrm{C} ; \mathrm{dP}(\mathrm{CDCl} 3)+22.58$ and $+27.55 ; \mathrm{dH}\left(\mathrm{CDCl}_{3}\right) 1.2\left(\mathrm{t},{ }^{3} \mathrm{~J}_{\mathrm{H}}-\right.$ $\mathrm{H}$ 7, $\left.\mathrm{CH}_{3}-\mathrm{CH}_{2}-\mathrm{O}\right), 1.85$ (m, $\left.\mathrm{CH}_{2}-\mathrm{CH}_{2}-\mathrm{CH}_{2} \mathrm{Cl}\right), 2.1$ (m, P-C-CH 2$), 3.73\left(\mathrm{t},{ }^{3} \mathrm{~J}_{\mathrm{H}-\mathrm{H}} 2.4, \mathrm{CH}_{2}-\right.$ $\left.\left.\mathrm{CH}_{2}-\mathrm{CH}_{2} \mathrm{Cl}\right), 4.03\left(\mathrm{~m}, \mathrm{CH}_{3}-\mathrm{CH}_{2}-\mathrm{O}\right)\right), 7.15\left(\mathrm{~d},{ }^{3} \mathrm{~J}_{\mathrm{H}-\mathrm{H}} 10.8, \mathrm{P}-\mathrm{C}=\mathrm{CHOH}\right)$. (HRMS) (Found $\mathrm{M}^{+}$256, 0632. Calc. for $\mathrm{C}_{9} \mathrm{H}_{18} \mathrm{ClO}_{4} \mathrm{P}: \mathrm{M}, 256.0631$..

O,O-Diethyl 1-(4-chlorobutyl) 2-oxoethylphosphonate $7 \mathbf{h}$ (50\%), b.p. $(20 \mathrm{mmHg}) 225-240^{\circ} \mathrm{C} ; \delta \mathrm{P}\left(\mathrm{CDCl}_{3}\right)+22.22$ and $+27.73 ; \delta \mathrm{H}\left(\mathrm{CDCl}_{3}\right) 1.3\left(\mathrm{t},{ }^{3} \mathrm{~J}_{\mathrm{H}}-\right.$ $\mathrm{H}$ 7, $\left.\mathrm{CH}_{3}-\mathrm{CH}_{2}-\mathrm{O}\right), 1.45-2.20$ (m, $\left(\mathrm{CH}_{2}\right)_{3}$ ), 2.95 (m, P-CH-CHO), $3.49\left(\mathrm{t},{ }^{3} \mathrm{~J}_{\mathrm{H}-\mathrm{H}} 2.3, \mathrm{CH}_{2}-\right.$ $\left.\left(\mathrm{CH}_{2}\right)_{2}-\mathrm{CH}_{2} \mathrm{Cl}\right), 4.13\left(\mathrm{~m},{ }^{3} \mathrm{~J}_{\mathrm{H}-\mathrm{H}}\right.$ and $\left.\left.{ }^{3} \mathrm{~J}_{\mathrm{H}-\mathrm{P}} 7, \mathrm{CH}_{3}-\mathrm{CH}_{2}-\mathrm{O}\right)\right), 7.33\left(\mathrm{~d},{ }^{3} \mathrm{~J}_{\mathrm{H}-\mathrm{H}} 10.5\right.$, P$\mathrm{C}=\mathrm{CHOH}), 9.63\left(\mathrm{~d},{ }^{3} \mathrm{~J}_{\mathrm{H}-\mathrm{P}} 2.66, \mathrm{P}-\mathrm{CH}-\mathrm{CHO}\right) ;{ }_{\mathrm{C}}\left(\mathrm{CDCl}_{3}\right) 16.3\left(\mathrm{~d},{ }^{3} \mathrm{~J}_{\mathrm{C}-\mathrm{P}} 6.5, \mathrm{CH}_{3}-\mathrm{CH}_{2}-\mathrm{O}\right.$ enol), 16.4 (d, ${ }^{3} \mathrm{~J}_{\mathrm{C}-\mathrm{P}} 5.4, \mathrm{CH}_{3}-\mathrm{CH}_{2}-\mathrm{O}$ aldehyde), 22.7 (s, $\mathrm{CH}_{2}$ enol), 22.8 (s, $\mathrm{CH}_{2}$ aldehyde), 25.7 (s, $\mathrm{CH}_{2}$ aldehyde), 25.8 (s, $\mathrm{CH}_{2} \mathrm{enol}$ ), 32.2 (s, $\mathrm{CH}_{2}$ aldehyde and enol), 44.4 (s, $\mathrm{CH}_{2}$ - $\mathrm{Cl}$ aldehyde), 44.9 (s, $\mathrm{CH}_{2}$ - $\mathrm{Cl}$ enol), 52.9 (d, JC-P 126.6, $\mathrm{CH}_{2}-\mathrm{CHO}$ ); 61.5 (d, ${ }^{2} \mathrm{~J}_{\mathrm{C}-\mathrm{P}} 4.9, \mathrm{CH}_{3}$ $\mathrm{CH}_{2}-\mathrm{O}$ enol), 63.0 (d, ${ }^{2} \mathrm{~J}_{\mathrm{C}-\mathrm{P}} 6.8, \mathrm{CH}_{3}-\mathrm{CH}_{2}-0$ aldehyde), 98.9 (d, JC-P 197.3, $\mathrm{C}=\mathrm{CHOH}$ ), $157.1\left(\mathrm{~d},{ }^{2} \mathrm{~J}_{\mathrm{C}-\mathrm{P}} 28.7, \mathrm{C}=\mathrm{CHOH}\right), 195.8\left(\mathrm{~d},{ }^{2} \mathrm{~J} \mathrm{C}-\mathrm{P} 3.6, \mathrm{CHO}\right)$. (HRMS) (Found $\mathrm{M}^{+} 270,0787$. Calc. for $\mathrm{C}_{10} \mathrm{H}_{20} \mathrm{ClO}_{4} \mathrm{P}, \mathrm{M}, 270.0787$.. 


\section{References}

1 G.M.Kosolapoff, J.Am.Chem.Soc; 1947, 69, 1002.

2 (a) D.Seyferth and R.S.Marmor, J.Organomet.Chem., 1973, 59, 237.(b) J.F.Normant, P.Perriot and J.Villieras,Synthesis, 1975, 458. (c) P.Coutrot, C.Laurenco, J.F.Normant, P.Perriot, P.Savignac and J .Villieras,Synthesis, 1977, 615. (d) J.Villieras, A.Reliquet and J.F.Normant, Synthesis, 1978, 27. (e) J.Villieras, P.Perriot and J.F.Normant, Synthesis, 1978, 29. (f) J.Villieras, P.Perriot and J.F.Normant, Synthesis, 1978, 31.(g) P.Perriot, J Villieras and J.F.Normant, Synthesis, 1978,33. (h) G.T.Lowen and M.R.Almond, J.Org.Chem., 1994, 59, 4548.

3 C.Grandin, N.Collignon and P.Savignac, Synthesis, 1995, 239.

4 (a) D.J.Peterson, J.Org.Chem, 1968, 33,780. (b) F.A.Carey and A.S.Court, J.Org.Chem., 1972, 37, 939. (c) C.Trindle, J.T.Hwang and F.A.Carey, J.Org.Chem., 1973, 38, 2664.(d) D.J.Ager, Synthesis, 1984, 384.(e) E.E.Aboujaoude, S.Lietje, N.Collignon, M.P.Teulade and P.Savignac , Synthesis, 1986, 934. (f) M.P.Teulade and P.Savignac, J.Organomet.Chem., 1988, 338, 295.

5 (a) E.E.Aboujaoude, N.Collignon and P.Savignac, Synthesis, 1983, 634.(b) G.A.Olah, L.Ohannesian and M.Arvanaghi, J.Org.Chem., 1984, 49, 3856.(c) P.Savignac and C.Patois Organic Syntheses, 1994, 72, 241.

\section{Acknowledgements}


We thank Dr J.P.Morizur (Universite Paris VI, ERS 72 CNRS) for the HRMS measurements. 